DOI: https://doi.org/10.15407/techned2019.05.068

\title{
AN OPTIMIZATION APPROACH BASED ON IMPROVED ARTIFICIAL BEE COLONY ALGORITHM FOR LOCATION AND CAPACITY OF GRID-CONNECTED PHOTOVOLTAIC SYSTEMS
}

Journal

Publisher

ISSN

Issue

Pages
Tekhnichna elektrodynamika

Institute of Electrodynamics National Academy of Science of Ukraine 1607-7970 (print), 2218-1903 (online)

No 5, 2019 (September/Oktober)

$68-76$

\section{Authors}

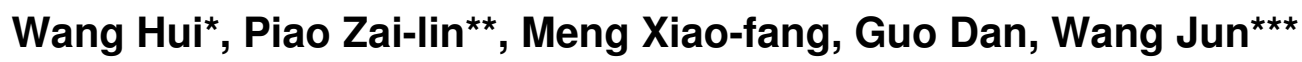

School of Information and Electrical Engineering, Shenyang Agricultural University, Shenyang 110866, China,

e-mail: hui87912@163.com ; piaozl@china.com

* ORCID ID : http://orcid.org/0000-0002-3002-3081

** ORCID ID : http://orcid.org/0000-0002-9453-3857

*** ORCID ID : http://orcid.org/0000-0003-4552-3158

\section{Abstract}

Access of photovoltaic system (PVS) to distribution network impacts voltage and power losses and also other related parameters. In order to make full use of the advantages of PVS and determine its optimal location and capacity, an optimal allocation's method for grid-connected PVS is proposed in this paper. This method takes the active power losses minimization as the optimization goal, divides the distribution feeder system into several paths to determine the path priority to install PVS according to active power load moment (APLM). The allowable maximum and minimum active power of grid-connected PVS for each bus are calculated via voltage sensitivity. The improved artificial bee colony (IABC) algorithm that selects initial solution by using path priority and active power restrictions of grid-connected PVS is applied to achieve the optimal allocation of PVSs. This method was examined with IEEE 33-bus feeder system, and the optimal locations and capacities for different numbers of grid-connected PVSs are determined. The results obtained by the proposed IABC algorithm were compared with the results obtained by the artificial bee colony $(A B C)$ algorithm and particle swarm optimization and those attained via other methods. The results show that the proposed method is feasible and 
effective. References 11, figures 7. tables 4.

Key words: photovoltaic power, path priority, active power load moment, voltage sensitivity, artificial bee colony algorithm.

Received: 13.06.2018

Accepted: 27.05.2019

Published: 01.08.2019

\section{References}

1. Tan S.W., Hassan M.Y., Majid M.S., Rahman H.A. Optimal distributed renewable generation planning: a review of different approaches. Renew Sustain Energy Reviews. 2013. Vol. 2. No 2. Pp. 626-645.

https://doi.org/10.1016/j.rser.2012.10.039

2. Abri A.R.S., El-Saadany E.F., Atwa M.Y. Optimal placement and sizing method to improve the voltage stability margin in a distribution system using distributed generation. IEEE transactions on power systems

. 2013. Vol. 28. No 1. Pp. 326-334.

DOI:

https://doi.org/10.1109/TPWRS.2012.2200049

3. Murthy N.S.V.V., Kumar A. Comparison of optimal DG allocation methods in radial distribution systems based on sensitivity approaches. Electrical Power and Energy Systems. 2013. Vol. 53. No 1. Pp. 450-467.

DOI:

https://doi.org/10.1016/j.ijepes.2013.05.018

4. Jamil M., Anees A. S. Optimal sizing and location of SPVS (solar photovoltaic) based MLDG (multiple location distributed generator) in distribution system for losses reduction, voltage profile improvement with economic benefits. Energy. 2016. Vol. 6. No 103. Pp. 231-239. DOI: https://doi.org/10.1016/j.energy.2016.02.095

5. Abdel-Salam M., El-Mohandes M.T., Shaker E. PSO-based performance improvement of distribution systems using DG sources. Proc. of 2016 Eighteenth International Middle East Power Systems Conference (MEPCON). Cairo, Egypt,

December. 2016. Pp. 866-870.

DOI:

https://doi.org/10.1109/MEPCON.2016.7836997

6. Kasaei J.M., Nikoukar J. DG allocation with consideration of costs and losses in distribution 
networks using ant colony algorithm. Majlesi Journal of Electrical Engineering. 2016. Vol. 10. No.1. Pp. 51-56.

7. Ahmad A.N., Musirin I., Sulaiman I.S. Exponential Based PSO Performed on DG Installation for Losses Minimization Considering THD. IEEE 8th International Power Engineering and Optimization Conference

(EOCO2014). Langkawi,

The Jewel of Kedah Malaysia, March 2014. Pp. 607-612.

DOI:

https://doi.org/10.1109/PEOCO.2014.6814500

8. Abbott R.S., Fox B., Morrow D.J. Sensitivity-Based Dispatch of DG for Voltage Control. Proc. of the 2014 IEEE PES General Meeting / Conference \& Exposition

. National Harbor, MD, USA, July 2014. 2016. Pp. 1-5.

DOI:

https://doi.org/10.1109/PESGM.2014.6939175

9. Gao F.W., Huang L.L., S.Y. Liu, Dai C. Artificial Bee Colony Algorithm Based on Information Learning. IEEE Transactions on Cybernetics. 2017. Vol. 45. No 12. Pp. 2827-2839. DOI: https: //doi.org/10.1109/TCYB.2014.2387067

10. Mohandas N., Balamurugan R., Lakshminarasimman L. Optimal location and sizing of real power DG units to improve the voltage stability in the distribution system using ABC algorithm united with chaos. International Journal of Electrical Power \& Energy Systems. 2015. Vol. 66.

No 2. Pp. 41-52.

DOI:

https://doi.org/10.1016/j.ijepes.2014.10.033

11. Kefayat M., Ara A.L., Niaki S.A.N. A hybrid of ant colony optimization and artificial bee colony algorithm for probabilistic optimal placement and sizing of distributed energy resources. Energy Conversion and Management . 2015. Vol. 92. No 3. Pp. 149-161.

DOI:

https://doi.org/10.1016/j.enconman.2014.12.037

\section{PDF}

